\title{
The End of the Profession as a Sociological Category? Systems-theoretical Remarks on the Relationship between Profession and Society
}

\author{
Thomas Kurtz ${ }^{1}$
}

Accepted: 16 March 2021 / Published online: 30 April 2021

(C) The Author(s), under exclusive licence to Springer Science+Business Media, LLC, part of Springer Nature 2021

\begin{abstract}
Following reflections by Talcott Parsons and Niklas Luhmann, this paper is concerned with the changing meaning of the profession as a sociological category for analyzing modern society. Professions are practical academic occupational groups oriented to certain social values, to which a special significance for society was attributed in the social sciences for a long time, thus marking a connection between professions' research and theory of society. This paper now describes that the causal relationship between profession and society is limited to a historically relatively early period. In the transition to modern society, this close network of relationships begins to dissolve, and now professions operate in the context of some function systems of society whose task is the professional assistance of single clients, such as in the fields of health, law, and pastoral care. However, the professions' highlighted position in the knowledge and action structure of single function systems seems to dissolve more and more today so that one can ask whether we can speak here already of an end of the social form profession. This would correspond with the observation that actually the professions no longer appear at all in the newer theories of society and therefore their function as an important mechanism of social structure formation is no longer attributed to them.
\end{abstract}

Keywords Social theory $\cdot$ Parsons $\cdot$ Luhmann $\cdot$ Profession and society $\cdot$ Organization

\section{I.}

The terms ,professional', ,pro', ,professionalism“ and ,professional action“ used in everyday language do not necessarily have anything to do with the existence of a profession. Professions are practical academic occupational groups oriented to certain

Thomas Kurtz

thomas.kurtz@dhge.de

1 DHGE, University of Cooperative Education, Campus Gera, Weg der Freundschaft 4, 07546 Gera, Germany 
social values, to which a special significance for society was attributed in the social sciences for a long time, thus marking a connection between professions' research and theory of society. However, it is noticeable that actually the professions no longer appear at all in the newer theories of society and that they are no longer ascribed the function as an important mechanism of social structure formation. And on the part of professions' research, this corresponds to a certain extent with a declining interest in societal analysis.

In the founding phase of sociology, this was entirely different. The concept of professions already appears in sociology as a social category in Herbert Spencer's Principles of Sociology of 1897, which defined the professions' development as the essential characteristic of civilized societies (see Spencer, 1966). For Émile Durkheim and Max Weber, for example, occupations and professions were regarded as central characteristics of modern society, and at the same time, as key phenomena for the theoretical capture of its structures. ${ }^{1}$ And at the end of the thirties of the last century, i.e. in the phase of the actual beginning of the sociology of professions as a sociological sub-discipline, this sociological discussion united with socio-political hopes, when Thomas H. Marshall (1939), for example, ascribes a service to society to the professional corporations in the succession to Durkheim and discovers in the professions a counterweight to the profit striving of the capitalist economy. It is well known that Talcott Parsons had considered the theory of professions, which he had developed since 1937, in a somewhat more differentiated way. But for him, too, the professions and, more precisely, the professional complex that summarized the professional occupational groups were the most important individual structure in modern society (see, for example, Parsons, 1937, 1968a).

However, this integral connection between professions' sociology and social theory seems to have been broken off after Parsons. Subsequent theoretical offers believed that they could mostly do without a corresponding reference - think of it as an example only of Jürgen Habermas' theory of communicative action, Pierre Bourdieu's field theory or Ulrich Beck's theory of reflexive modernization. Exceptions here may be the theory of the knowledge society, which refers back to the particular form of knowledge work (such as Stehr, 1994), or systems theory. However, from a systemstheoretical perspective, the significance of the professions for society and its theory is increasingly becoming a historical topic, and the sociology of professions is transformed into a more general theory of global epistemic communities. ${ }^{2}$ While Parsons still examines professions in the context of society as a whole, systems-theoretical analyses are more concerned with the significance of professions in the context of single function systems of society. ${ }^{3}$

If one now asks from this particular analytical perspective about the significance of professions in modern society, it makes little sense to follow approaches that additively list descriptive characteristics for the determination of professions and concede

\footnotetext{
${ }^{1}$ See Durkheim 1902; Weber 1985. While Durkheim determined the occupational group as a mediating link between individuals and society, Weber was particularly interested in the consequences for modern capitalism resulting from professional ethics.

${ }^{2}$ See Stichweh 1996; 2006. See also Kurtz 2005: 135-186, on the relationship between profession and society.

${ }^{3}$ In Niklas Luhmann's systems theory, function systems are understood as social subsystems such as politics, education, religion, economy, science, art, and law (see for example Luhmann 2000; 2008).
} 
successful professionalization while fulfilling a majority of the characteristics and criteria listed in these lists (such as Cogan, 1953). Other approaches do not seem to be much more helpful for the question addressed here: In terms of power theory, the question has been asked as to how professions contribute to the maintenance of society on the one hand, and in what way society, which depends on them, grants them a multitude of privileges on the other (e.g., Larson, 1977). Or, however, an attempt is made to include occupational activities in the sense of an ascending order of rank from work to occupation to profession (Hartmann, 1968) in the group of professions that are particularly highly regarded in society, whereby this is understood explicitly as an ascension project primarily in the context of debates on legitimation and professional status. In the 1960s, this can be observed in particular in the aspired professionalization of occupations such as social work or teacher work and today, perhaps in the broad field of company training and further education.

These attempts to include as many occupational groups as possible in the concept of professions are, however, also questionable from the point of view of their approach (cf. already Wilensky, 1964), since they encourage inflation of the concept of professions, which makes it difficult to discern what actually seems to be special about these occupational activities. ${ }^{4}$ In any case, this inflationary use of the term profession is striking in that it combines heterogeneous activities which, as the only common feature, have particularly demanding training and qualifications. However, this is nothing special anymore in our increasingly knowledge-based society. In contrast to these profession-sociological approaches, the following considerations are guided by a society-theoretical observer perspective (Kurtz, 2000). I.e., this is about the relationship between profession and society.

\section{II.}

Contemporary sociology knows several ways of communicating about society and has different concepts of society at its disposal for these so-called self-descriptions of the social system. The initial form of a description of society that can be reduced to one single term of society is certainly the class society stated by Karl Marx as the result of the dissolution of the birth-related order (see for instance Marx \& Engels, 1974/1848), which in the analyses of the twentieth century was increasingly replaced by industrial society (see Aron, 1962). Such descriptions of society already contain their content in the term of society and show what they consider to be the outstanding characteristic of modern society. When one emphasizes the thorough organization of society, one can speak of the organizational society (see Schimank, 2001), when it comes to certain cultural issues, then one calls the society the experience society (Schulze, 1992), when it comes to ecological problems, then one speaks of the risk society in science, but also in politics and the media (Beck, 1992), and when it comes to questions of work, education, and innovation, then, across all system boundaries, one speaks of the knowledge society.

Anyone talking about the modern knowledge society today very rarely refers to Talcott Parsons concerning its theoretical background, but mostly to the already classic study by Daniel Bell,The Coming of Post-Industrial Society from 1973 (Bell, 1973).

\footnotetext{
${ }^{4}$ See Kurtz 2013 on the relationship between occupation and society.
} 
However, Parsons published his study The American University together with Gerald M. Platt in the same year (see Parsons \& Platt, 1973), and it is noticeable here that both books come quite close in their core statement; in both the university is worked out as the innovative core structure of modern society. While Parsons' theory of the professions has turned out to be a theory of the university and the knowledge system of society, ${ }^{5}$ for Daniel Bell, the university forms the basis for an analysis of modern society in the transition from the industrial to the post-industrial or knowledge society.

We can only speculate about why the university book by Parsons and Platt has mainly remained unnoticed compared to that by Daniel Bell. It is probably not because Parsons has always avoided the concept of the knowledge society and preferred the concept of a functionally differentiated society. Rather, this is because Parsons' theory had already passed its climax at the time of publication of this study and that little attention was paid to it in both the USA and Europe. Whatever this disregard may have been, it is worth asking in this context, on the one hand, what Parsons' considerations led to the development of this theory and, on the other hand, the significance of this study on the American university for a theory of the knowledge society. ${ }^{6}$

Parsons' reflections on the professions were first and foremost a reaction to the world economic crisis. Like Durkheim, he wondered whether the social order could be left solely to the individual's desire for the benefit, or whether one should not also consider overarching value systems. However, he found these values less in the business world, which aimed at self-interest, than in the professional occupations (Parsons, 1939), which were committed to an altruistic ideal of service, including leading activities in the fields of medicine, education, and welfare. Moreover, in this comparison of the economic occupations with the helping occupations, Parsons was the first to point out that it is not only the economy that acts rationally - in Weber's sense zweckrational ${ }^{7}$ but also the professional occupations that orient themselves towards rational and, in particular, value-rational action. He interprets professional action as rational action (see also Stichweh, 1980), which is based on scientifically generated knowledge, art teachings, legal norms, etc., and which refers back to cognitive standards. It combines rationality and action-oriented knowledge composed of different contexts of justification to overcome the problem of the social integration of the members of society. ${ }^{8}$

\footnotetext{
${ }^{5}$ Parsons speaks here more precisely of the cognitive complex of society.

${ }^{6}$ Parsons had already identified the universities as the cornerstones of the emerging knowledge society, particularly in the Section ,The Educational Revolution and the Contemporary Phase of Modernization“ of the book The System of Modern Societies, where great importance was attached to the professions that applied academic knowledge (see Parsons 1971: 94-98): „The competence required in the professions is generally attainable only through advanced formal training, which now occurs in academic settings. The modern university has thus become the keystone in the professional arch. The profession par excellence is the academic, the profession of seeking and transmission knowledge. It is surrounded by a ring of professions charged with applying knowledge to social order (law), health (medicine), effectiveness in governmental and private collectivities (administration), efficient use of the non-social environment (technology), and so on. The educational revolution, through the development of the academic complex and channels for applying academic competence, has thus begun to transform the whole structure of modern society. Above all, it reduces the relative importance of two major ideological concerns, the market and bureaucratic organization. The emerging emphasis is on associational organization, especially its collegial form" (Parsons 1971: 98).

${ }^{7}$ See for this term Parsons 1968b: 642ff.

${ }^{8}$ Parsons distinguishes the practical academic professions from other occupations: While occupational roles are usually differentiated in the ,,adaptive subsystem “ (economy) (see Parsons 1954: 420), professions are not so much oriented towards the economic system as towards society as a whole (see also Hartmann 1968).
} 
Parsons has repeatedly stressed that the professions occupy an almost unique position in our society, in that they administer on a fiduciary basis for society the respective socially central value aspects such as education, justice, health, and truth. ${ }^{9}$ Together, the professional occupation groups form the professional complex that unites the professional groups who, based on highly specialized knowledge combined with fiduciary responsibility for the general public, work as experts for laypersons on certain aspects of their personal lives (Parsons, 1978: 40). In a 1968 contribution, Parsons interpreted this complex as the most important single component in the structure of modern societies and even went so far as to assert that in the future, this professional complex would dominate the contemporary scene and replace the forms of political authority and capitalist exploitation (see Parsons, 1968a).

Apart from this vision of the future at the political level, which emerges on Parsons' work margins, he is more concerned with describing the processes that have led to the development of modern society. And he shows that the professional complex is closely interwoven with the cognitive complex (knowledge system), because it has not only emerged from the (European) university, but also encompasses the function of practical application of knowledge (practice) in professional/client interactions, as well as the functions of research and mediation of the relevant knowledge, whereby ,the research function $(. .$.$) is to improve the cognitive base underlying both practice and teaching { }^{\text {" }}$ (Parsons, 1978: 63).

While in modern society occupations can be found in every social subfield, the existence of professions is limited to some particular ones (Kurtz, 2005). In this sense, Talcott Parsons and Gerald M. Platt distinguished two groups of professional occupations in their study of the American university: university teachers, engineers, physicians, and lawyers operate at the level of the general action system, and the professions in education, welfare, administration and accounting, and banking, on the other hand, perform functions within the social system (Parsons \& Platt, 1973). However, the importance of professions for society as a whole, which is reflected in the formulation of the ,professional complex“ as an essential structural feature of modern societies, but also the importance of Andrew Abbott's ,system of professions“, which introduces his eponymous profession sociological main work with the statement „The professions dominate our world" (Abbott, 1988: 1), is questioned in systems-theoretical contributions. ${ }^{10}$ For the causal relationship between profession and society is limited to a historically relatively early period. In contrast, in the transition to modern society, professions operate in the context of single societal function systems, namely those that deal with inclusion problems. Thus, systems are addressed here in which the first and foremost goal is to help people with their problems. Compared to the relatively broad version of Parsons and Platt, we restrict the concept of professions; the reference point of professions is neither the whole society, nor are they found in every sub-sector of society. Professions in modernity are a special form in the context of some social subsectors, but this form is not above the form of functional differentiation of society.

\footnotetext{
${ }^{9}$ Parsons locates the professions in the fiduciary system, which marks the interpenetration between the social system society and the cultural system.

${ }^{10}$ Cf. already Stichweh 1996: 49; 1997: 96, who refers against Parsons and Abbott to the primacy of functional social differentiation. If one starts from autonomously operating social sub-areas, it is difficult to imagine a bridge principle symbolizing the unity of these systems.
} 


\section{III.}

At present, systems theory seems to be the only social theory in which both organization and profession are treated as mechanisms of social structure formation, without claiming to be a focal point in theory (see Kurtz, 2011). For example, Niklas Luhmann repeatedly describes organizations and professions as forms of „re-specification of criteria that are plausible for society as a whole but have become too general". ${ }^{11}$ On the other hand, organization and profession play an important role in systemstheoretical societal analysis in the question of how the uncertainties of communication can be reduced in society (Kurtz, 2005: 136ff.).

In this regard, Luhmann first referred, following Parsons, to the so-called symbolically generalized communication media such as truth, money, power, art, and love, which act here as motivational boosters of communication and thus guarantee or enable communicative connectivity. Nevertheless, these media alone are not sufficient to continue communication but require additional formal organizations. While the media tend to loosely couple the communicative elements, it is only organizations with their decisions that lead to fixed, person-independent and permanent forms, so that symbolically generalized communication media and formal organizations both contribute in different ways to the probability of the improbable (see Luhmann, 1987: 41). While organizations have now established themselves in almost every function system, the symbolically generalized media of success cannot be observed in the function systems that deal with inclusion problems and whose fulfillment of function lies in a change in their personal environment - i.e., people, their bodies and structures of consciousness. There seems to be such a socially differentiated medium of communication neither for education and health nor religion and law. Interestingly, it is precisely in the environment of these functional areas that professions have developed that attempt to fulfill the function of the system at the level of action. Therefore, professions do not complement the symbolically generalized media like the organizations that can be found almost everywhere, but function in some systems as their replacement (see Kurtz, 2000 for more details).

Niklas Luhmann had already hinted at the relationship between professions and functional differentiation in the nineteen-seventies in his study on religions' function although he did not associate this with his theory of communication media at the time. Luhmann had emphasized there that in the course of the functional differentiation of society, ,duals“ or ,binary schematisms“ have developed, through which two worlds or states are generated, which figure as opposites, such as have/not have, true/untrue, and are „highly technological“ (Luhmann, 1977: 204), by deciding, for example, for one or the other side of the form, that is, for paying or not paying. For the functional areas of religion, education, and health, however, this technological functionality is not guaranteed, so that in these cases, the respective professions have a mediating function: professional practitioners have to mediate between the two sides of the distinction in

\footnotetext{
${ }^{11}$ Luhmann 2002: 143 - own translation; see in addition Kurtz 2004a. Here, it is about how the general goals of the respective function systems can be practically implemented via organization and profession - see for the example of the educational system Kurtz 2020.
} 
interaction contexts and cooperation with the clients, more precisely: work from negative to positive value - from worse to better performance, from sick to healthy, etc. $^{12}$

In this sense, professions in modern times are those occupational groups that interpret, administer and work on clients' practical problems in the context of single function systems such as the health, legal, religious and educational systems in interaction situations with clients. Professionals such as doctors, lawyers, pastors, and teachers act as the professional performance roles of these social systems. Here we find monopolized performance roles, which are of particular importance in the differentiation of systems in the transition to modernity and their fulfillment of the system-specific performance for other function systems of society (see Kurtz, 2005: 135ff.). How does one explain that?

Hannes Siegrist (1988: 42) has described the nineteenth century as the century of professions. Moreover Rudolf Stichweh (1997: 95) formulates the thesis that „Professions are a mechanism of transition from the society of estate of early modern Europe to the functionally differentiated society of modernity", and that it is above all in this that they have their significance for the history of society. Thus, no general agreement has been reached on the professionalization processes in the world's most diverse regions. In a pointing that is certainly losing some of its depth of field, one can draw a line between the Anglo-American (England, USA) and the continental European (Germany, France) development. ${ }^{13}$ The starting point for the emergence of self-governing professions in the Anglo-American region was marked by the English Inns of Courts and the Royal Colleges of Physicians in the fifteenth and sixteenth centuries (cf. Burrage, 1988: 53ff.). In particular, the corporate associations of lawyers, whose name derives from the fact that practicing lawyers and legal trainees lived together in inns near the royal courts, serve as models for other professional groups. In the associations, both the more practical training and examination of the junior staff were administered, and the observance of order within the profession was ensured. The situation of the professional occupations in Germany and France is shown in the form of a contrasting foil. In the beginning, these were characterized more by the handling of attempts by the state to patronize them and about their knowledge base, more by the differentiation processes between academic-scientific and practical process knowledge. The current situation is generally characterized by the fact that the professions everywhere are characterized by a combination of partial autonomy and state influence as well as an academic-scientific education. At any rate, this is true in the regions of the world where the primacy of functional differentiation of society has prevailed. In systems-theoretical terms, these differences result from the fact that the professions operate in the context of different nation-state segments of the function systems of education, health care, law, and

\footnotetext{
${ }^{12}$ But this is precisely where a problem arises: both the professional work and the operation of the respective function system are an intervention in the environment of the communication or the system. They can only be regarded as successful if this changes. However, since clients can always react very differently than the professional would have imagined and professional work generally depends on the cooperation of the clients teachers cannot relieve their students of learning, patients have to take their medication regularly and the priest cannot believe for the believer or unbeliever - we are dealing here fundamentally with a highly uncertain work, but also with special uncertainies of single function systems; see also detailed Kurtz 2006a.

${ }^{13}$ See McClelland 1985 for an example of the genesis of the professions in Germany; Geison 1983 in the USA; Geison 1984 in France; and Burrage and Torstendahl 1990 in general.
} 
religion. Concerning the respective social system, all early modern professions work beyond national borders on what we describe today as the treatment of inclusion problems of function systems.

While organizations are only a manifestation of modern society, professions are already an important form of structure formation in early modern Europe. From the three classical professions of theology, jurisprudence, and medicine, the only scientific faculties of the medieval and early modern university in Europe emerged in the narrower sense, while the philosophical faculty, in which the artes were taught, was not regarded as a scientific faculty (Stichweh, 2005: 31). In this sense, the professions at that time administrated, so to speak, the scientifically relevant knowledge of society. But not only that: in professional practice with clients, the professions marked a complete classification of all important human external relations - i.e., relations to oneself (medicine), to God (theology), as well as to other, mostly quarreling persons (law). ${ }^{14}$

In the transition to modern society in the nineteenth century, in the differentiation of independent social subsystems, this hierarchy between the faculties was fundamentally reversed. While new scientific disciplines are emerging in the philosophical faculty, professional knowledge systems are increasingly turning into application-oriented disciplines. However, this does not mean the end of the social form profession. Even in the transition to modernity, the profession remains an important structural form of society, which can no longer relate to society as a whole but to single societal subsystems. Until the early modern era, the professions administered the knowledge of society and represented in their practical work all essential social problem relations of the people, so that in the stratified society they could refer to the whole society, while since the nineteenth century they orient themselves more and more to the respective function of those social sub-areas which deal with inclusion problems. Inclusion here means participation in social communication and a change in the client's person via medical, religious, and - reduced to conflict therapy aspects - also legal professional care.

What is special about this is that we are dealing with function systems in which the unity of the system is ultimately symbolized by only one occupational group: ,monoprofessional function systems" (see Stichweh, 1997). Here a leading profession administers the particular knowledge of the function system at the level of action and has a control and delegation function vis-à-vis the other occupations working in the system's context. And this does not simply mean the relationship between the superior and the subordinate. However, the point here is that in these social subsystems, a single occupational group dominates the action, something that we do not find anywhere else in modern society. While in the early modern period, for example, there was no exclusive monopoly on healing, but rather a diversity of offers on the health market, which were provided essentially equally by the three professional groups of learned doctors, artisanal barber-surgeons, and executioners ${ }^{15}$ in the nineteenth century, the

\footnotetext{
${ }^{14}$ See Stichweh 1992: 37 . The close coupling of scientific and practical knowledge observed here in early modern Europe has been maintained in these three subjects to this day. Here also, the university teachers belong to the profession, and it is not unusual thereby if these are active also still as practical professional men: for instance, representing clients in court, caring for patients or preaching in church.

15 - and which did not differ significantly in terms of their treatment options and prospects of success at the beginning because they were all equally poor (Stolberg 2004: 120) -
} 
academic medical profession achieved the monopoly of definition for who in society should be considered healthy and who sick. ${ }^{16}$

As can be seen from these remarks, this is a professional concept, which deviates in many ways from the usual idea of what that is: a profession. Many professional concepts can be reduced to the characteristic of particularly demanding training and qualifications, which, however, is nothing special in our increasingly knowledge-based society. Look at the sociological literature on the classical professions of doctors, pastors, lawyers, and teachers, you will see that, in addition to the special knowledge-based nature of the professional occupations, there are at least two other criteria that one can find in the symbolic interactionism of Everett $\mathrm{C}$. Hughes and the structural functionalism of Talcott Parsons. On the one hand, this is about working on the problems of individual persons - that is, persons in need of consolation or salvation, sick, quarreling, and having to be educated -, problems that are to be solved in interaction contexts between the professional and the client (see Hughes, 1958a, 1963). On the other hand, this approach to problems with clients only leads to the emergence of professions if the desired solution of the problems enjoys high social esteem, i.e., if the work covers special social values such as faith, justice, health, and education (see Parsons, 1939, 1968a). Knowledge foundation alone is therefore not yet a sufficient criterion for profession's existence; at least the relation to society and the problem solving of and with clients in interaction situations are always added.

In this perspective it becomes also questionable whether the foundation of a profession can be a realistic perspective for the development of sociology, as is repeatedly put up for discussion by certain areas of applied sociology in the framework of calls for a stronger practice orientation in study programs. However, regardless of whether one focuses on our or on another concept of profession, it is difficult to imagine sociology as a science of action oriented towards a practical profession. For sociology, however, the situation is fundamentally different: Sociology dominates neither the theoretical nor the practical guidance of a function system. For this, it lacks above all its own personally bound and case-oriented practice. Indeed, this calls to mind the US debate from over six decades ago, in which a quite different picture of the future of sociology was presented. For instance, it is clear from the works of Everett C. Hughes (1958b), Talcott Parsons (1959) and William J. Goode (1960) that all three are in agreement that sociology should seek a profile more as a scientific discipline than as a practical profession. ${ }^{17}$

The modern professions of the twentieth century are thus oriented towards the respective functions of those social sub-areas which are primarily concerned with individual persons' help and must carry out the same reductions as these at the level

\footnotetext{
${ }^{16}$ See Huerkamp 1980. The prerequisite for the associated transition to the modern physician and the special form of the medical view was the development of the organization hospital as well as an autonomous medical knowledge production (Foucault 1963).

${ }^{17}$ In this regard, Hughes (1958b: 166 f.), for example, wrote: "I think I can assume that we are all more interested in the advancement of sociological knowledge than in the advancement of a profession of sociology." But this was exactly the idea of Michael Burawoy (2005), who wants to extend the professionalized academic sociology by a publicly effective sociology. When he speaks of professional sociology, however, he understands it to mean the methods and knowledge of the discipline rather than their practical application. The quite understandable talk of a professional sociology does not mean, nevertheless, that sociology is at the same time a profession in the classical sense. On the relationship between sociological theory and sociological practice, see Kurtz 2007.
} 
of action. In such a theoretical perspective, professionalization can be described as: „everywhere where a significant cultural tradition (a knowledge context), which in modernity has been differentiated in the form of the problem perspective of a function system, is used in interaction systems in terms of action and interpretation by an occupational group specializing in this task for dealing with problems of structural change, structural development and the preservation of the identity of individuals." 18 Professions thus adopt the internal perspective of the respective function systems and address their inclusion problems at the level of action. The professions manage a form of knowledge, ,which is an essential component of the European tradition of science and which furthermore, as an action oriented knowledge system on scientific foundations (i.e. as dogmatics), is fundamental for professional action in the respective function system" (Stichweh, 1997: 97). However, the knowledge to which the professions refer in their work is not only scientific knowledge but the knowledge of the systems in the context of which the professions operate. Pedagogy, medicine, jurisprudence, and theology are self-descriptions of education, health, law, and religion.

\section{IV.}

However, if one looks at the current situation, it seems questionable whether there will be other function systems in the future whose knowledge base can be managed and controlled by a leading profession operating in a monopolistic or dominant position. And besides, it can still be observed today that this special form is also beginning to dissolve in the systems of education, health, law, and religion. Following Rudolf Stichweh (1997), the form profession can be described as a transitory phenomenon that has already passed its peak. Stichweh justifies this with the increasing implementation of evaluation and auditing, which are carried into the systems from outside. Today, the actions of professionals are increasingly subject to external observation and evaluation. ${ }^{19}$ However, all these external observations and communications to the respective system do not become operations of the evaluated system but operate in the context of the evaluating system. With this additional perspective of second-order

\footnotetext{
${ }^{18}$ Stichweh 1992: 43 - own translation. Professions will only be assigned to those function systems that are characterized by a fundamental interaction dependency. But not to be misunderstood here: of course, this does not mean that there would be no interaction in other systems. Interactions or interaction systems can be found in every area of society, in every function system, every organization and network. But while systems such as the political system are not necessarily dependent on interaction, in which the administration of political power by politicians and the voting of parties and politicians by voters can be exercised very well in separate situations, the interaction between present experts and clients in the monoprofessionalized systems of education, law, health, religion and - with some limitations - social help has become a fundamental component of the respective systems. Besides, it is not only a matter of continuing the system's communications, but also of intervening in the persons, their bodies and structures of consciousness. Communication here is only successful if people change, if they believe again or even more strongly, are healed and educated.

19 ,The professionalized function systems and their formal organizations are progressively joined by specialists for economic, juridical and organizational questions. Their function is to re-analyse the ways of observation that are established in the professions by a second-order observation via incongruent perspectives. That means that professional dominance and the self-control of the professions is substituted by a situation in which there always exists one more observer who evaluates the distinctions that are made, and the success in using them, by the application of a heterogeneous set of distinctions" (Stichweh 1997: 99f.).
} 
observation, the observed system is irritated but not determined. Supervision is then always only a stimulus for self-change.

In addition to these external irritations caused to the systems by auditing, evaluation, and supervision, significant internal changes can also be identified, which will be briefly discussed in the concluding remarks on the form profession. In education, medical treatment, law, and religion, for example, professional work today is increasingly influenced by distribution media such as televisions and computers, with the result that the professions are slowly losing their formerly prominent role for these function systems' communication processes. One can then ask about the educational value of the Internet or the sense of confession with confession programs and selfmedication with medical advisors. For example, in the context of the legal system, it has been possible for some time now to obtain legal advice around the clock by telephone from tele-lawyers. And in the USA, many children, also already before the Coronavirus, learned at home in front of the screen, without the profession of teacher and school organization.

In the field of education, for example, one can generally see that with the advent of the new media, self-organized learning is gaining more and more influence. ${ }^{20}$ And in connection with the development of imaging diagnostics from the invention of x-rays in 1895 to the computer-assisted visualization technology of ,,magnetic resonance imaging“, there has also been a change in the system of medical treatment to the effect that the physician's understanding of the body seems to be moving further and further away from the real physis (see Gugerli, 1999). These examples show that in the functional areas mentioned here the interaction dependency of the communicative operations of the system is partially softened with regard to the problem handling of persons. Although mutual perception between experts and clients has so far largely described the situation of professional work, there seems to be a reversal of this trend.

However, other internal changes can also be identified, such as the trending change in the special asymmetric relationship between the professional performance role and the complementary client role. Until the beginning of the nineteenth century, patients dominated the relationship with doctors due to their origin (see Waddington, 1978). And today, one can find examples where the asymmetrical relationship between doctor and patient partly turns back in favor of the public due to the variable knowledge. One no longer speaks of the imaginary sick but the educated sick (and healthy). The doctorpatient relationship has already changed because more and more patients consult the Net for health information, demand therapies not available in their country, and obtain medicines not yet approved in the Internet pharmacy. But beyond that, there are already patient organizations in the form of medical self-help groups, which in the USA are already regarded as a new power in the health care system, which provides patients with the latest scientific research results for unusual and little researched diseases and places doctors who specialize in these diseases or act as advisors to other doctors. This can mean that the patient organizations finance medical research projects or that they carry out research. Initial policy responses to these trends can be observed in the UK,

\footnotetext{
${ }^{20}$ See Kade and Lüders 1996. However, it should be pointed out here that knowledge transfer without a pedagogical performance role is not an invention of the modern knowledge society. See, for example, Giess 1999, on the early history of pedagogical knowledge transfer using the example of the so-called popular calendar (,Volkskalender") in the popularization of knowledge.
} 
where the Department of Health is trying to systematically integrate patients' knowledge and experience with chronic diseases into the health care system.

However, profound changes can also be observed in the other functional areas: There are new religious movements in the religious system that manage without a professionalized performance role, or where, as in Christian Science, the temporary performance role is recruited from the audience. The experts are confronted with experienced practitioners in scientific continuing education and in other forms of continuing education. And students are often much more competent with computers than their teachers. Finally, in the legal system, we observe the private arbitral tribunals, whose performance roles do not have to consist exclusively of trained lawyers. Although their decisions have already been recognized and enforceable in some 130 countries of the world since 1958 as a result of a United Nations agreement, their importance has also increased rapidly in the recent past. The reason for this is relatively simple, private civil courts are quicker, cheaper, and the decided cases cannot be reopened as in the classic judicial system. Nevertheless, we cannot assume that the respective structural differences in knowledge between the social types of expert and layman will converge, but rather that new experts will form here, that is, that some laymen will become experts. ${ }^{21}$

In summary, it is first of all undisputed that professions have assumed a supportive role in the differentiation of some social functional areas due to their dependence on interaction. However, it is equally undisputed that the differentiation of other occupational groups in the context of these systems, the changes in the relationships between experts and clients, and the differentiation of the media leading communication are all leading to a decline in the formerly prominent position of the professions in these function systems. Of course, doctors, even if their budgets are cut from the outside, still have the monopoly of definition for the question of who is healthy and who is ill, and the law is still spoken by judges. Nevertheless, it is noticeable that the form of multiprofessional and multi-dimensional problem solving by and for persons, as we find it in the system of social help, ${ }^{22}$ indicates a tendency to which the function systems of education, medical treatment, law, and religion also move. Like the occupational groups in the context of social work (see Kurtz, 2004b), lawyers, doctors,

\footnotetext{
${ }^{21}$ One can generalize what has been said here beyond the boundaries of the professions. Jürgen Gerhards does not speak of new performance roles recruited from the audience but empirically shows that in the (professionalized) systems of health care, education and law, as well as in other systems such as art, politics, and economics, a change in the relationship between performance roles and the audience of function systems can be observed between 1960 and 1989. As the audience stands up against the functional role carriers, the relationship between audience and performance roles has been recoded (Gerhards 2001: 167). See also the considerations of Alfred Schütz (1946) on the so-called ,well-informed citizen“.

22 The question of whether social work is a profession was posed relatively early and attempted to be answered; see Flexner 1915, for example. Parsons and Platt have emphasized ,the problematic character of their cognitive basis“" $(1973: 248)$, which was one of the reasons why social work was not granted the status of a fully trained profession, but that of a semi-profession with a high proportion of paraprofessional personnel; see as examples Austin 1978; Toren 1977; Etzioni 1969. Finally, for some years there have been voices that emphasize the special nature of social work: Andrew Abbott problematizes social work as ,the profession whose job was to mediate between all the others. (...) The social function of social work was intersystem translation“ (Abbott 1995: 549). While Stichweh (1997) fixes here the problem of social work, which cannot offer independent functional expertise due to the care of diffuse problem situations, one could also argue that social work not only observes a section of human life like the classical professions but must try to integrate all these observations. Social workers are always deployed when other professions no longer know what to do.
} 
pedagogues, and theologians are increasingly operating in organizations that do not follow their system's functional primacy and are thus acting in the context of different social guiding distinctions. The different occupational groups in the systems of education, medical treatment, law, religion, and social help all work with the medium of the person or his/her life career. But for each of these systems and professions, the person appears with a different excerpt, so the medium requires a different shaping.

Dieter Lenzen (1991) has vividly described along the human life career that in the system of medical treatment from perinatal medicine to in-vitro fertilisation to euthanasia, more and more areas of activity have been invented in recent years, which in their work have very little to do with real illness, but also with the value ,sick', which was formerly normal: e.g. the process of birth. And when cosmetic surgery emerges as a field of activity that no longer necessarily operates on the code sick/healthy, this does not initiate a de-differentiation of the system codes, but rather, as professional work increasingly moves away from the binary value of the function systems, the dissolution of the social form profession. So as not to be misunderstood: It is not a question of denying, on an action-theoretical level, the still high relevance of professionalism for problem-solving by and with clients, but only of demonstrating that, on a level of communication and societal theory, individual professions no longer dominate the communication processes of function systems, which are oriented along with binary distinctions, and can symbolize the unity of such a system.

What can we infer from that? Following the example of Harold Wilensky (1964), one can once again ask oneself whether the concept of professions should be extended to include politicians, advertising specialists, tax consultants, cultural practitioners, engineers, social workers, and management consultants. If one distinguishes between the social form profession, which (has) marks the structure of some function systems in society, and professionalism or professional action, then the current situation can be described by two opposing tendencies, which seem to contradict each other only at first glance: On the one hand, the function systems of the society can be less and less determined by the classical leading professions, and on the other hand, we observe an increase in the importance of professional performance provided through professional action.

But not only in the professions, also in the so-called knowledge occupations, professional action is taken and professional performances provided. The different groups of knowledge workers and/or owners of knowledge occupations do not represent certain function systems in modern times, nor society as a whole, but the structure of action of these increasingly large occupational groups is similar to that of the classical professions. Both the professions and modern knowledge occupations are not necessarily about more knowledge, but about a special form of knowledge. It is about the distinction between knowledge and non-knowledge, whereby non-knowledge and knowledge of this non-knowledge are just as important for action as what professionals and knowledge workers know. And it is precisely at this point that the classical professions meet the new knowledge occupations, without the latter having to do with clients' practical problems or having to cover central social values. Like the knowledge of the professions, the expert knowledge of the knowledge occupations also needs to be interpreted, is contingent, and reproduced again and again in action. And like the knowledge of the professions, this knowledge does not lead to correct problem solutions but rather to problem interpretations. 
In general, however, it can be said that with the increase in knowledge, more and more occupations are becoming knowledge occupations, so the term knowledge occupations is thus a term of increase. However, the term profession is quite different because it is not only based on knowledge but also says a lot more. Professions can only ever be a few occupations. Profession is an exclusive term, but it does not denote a hierarchy over other activities. After all, even professionals do not get more money for their work as knowledge workers; their costs are calculable, while those of experts as knowledge workers can increase immeasurably.

\section{V.}

The formation of structures in the form of a mono-professional function system, however, seems to have reached its end today, as a result of which the form organization reorganizes the division of labor in these systems as well. In contrast to other theories of society, which simply no longer address the professions, we find in systems theory an explanation for the end of the form profession as a structure-building mechanism of society. Niklas Luhmann had already introduced his previously unpublished text on professional work from the 1970s by astonishment at a peculiar interest in the peculiarities of professional practice in recent sociology, and this because the tendency would have to go in the direction of other topics (see Luhmann, n.d.: 1). That fits quite well with the observation of Stichweh that the sociology of professions began in the 1930s at a time when the principle of professionalization could already be regarded as outdated (Stichweh, 2005: 36f.). Luhmann then justifies this unusual interest in the professions with the socio-political hopes that sociology was able to discover and awaken in the profession model at a time when capitalism was in crisis. And this already began with Parsons, whose reflections on the professions were essentially also a reaction to the world economic crisis; for him, professional occupation groups committed to an altruistic ideal of service contribute in a special way to maintaining the social order of society.

Today, however, one can see that even in the professionalized function systems, the organizations seem to dominate the system events more than the professions. That can already be seen from the fact that professional work is increasingly dependent on an organization (see Harries-Jenkins, 1970). Although not all professionals work in organizations, they are all dependent on organizations for their more or less independent work in their environment. However, this does not also apply vice versa; organizations are not necessarily dependent on their members organizing themselves in professional associations beyond the individual organizations at the same time. In modern society, at any rate, the action knowledge of function systems is deposited more and more in the form of organized knowledge management in organizations. What is possible in society is decided less in the professions and more in the organizations of function systems.

Thus, the form profession refers to the system-internal differentiation of the systems of education, medical treatment, law, and religion and thus indicates a parallel development between these function systems and the leading professions operating in their context for a certain period in the history of society. The unusual structure formation in the form of a mono-professional function system seems to have reached its end today, 
as a result of which the social form organization reorganizes the division of labor in these systems as well (see Stichweh, 2005: 41). The mono-professionality in education, health, law, and religion is beginning to disintegrate, and we find there - similar to the systems whose knowledge base could never be administered by a single occupational group - a heterogeneous and pluralized occupational structure. Nevertheless, not necessarily another occupational group gains a dominant position in the systems, but rather it can be observed that on the one hand, the action-knowledge of the function systems is deposited more and more as a form of organized knowledge management in the organizations in which the different performance roles are socialized and on the other hand that organization as a coordination service of work, actors and knowledge determines more and more the social order of professionalism. Seen in this light, the profession as a societal form is a transitory phenomenon that has already passed its peak.

Today, however, individual professions have less and less exclusive access to certain problem definitions and solutions. On the other hand, in modern society we can observe an erosion of the complete controllability of individual function systems' knowledge stocks. The fact that professional knowledge is available to almost everyone through technical distribution media means that it cannot be removed from the grasp of laypersons or other occupational groups - it is, as it were, disenchanted and exposed to criticism through the media's ability to mobilize this knowledge. And this is one reason why the form profession no longer plays such a prominent role in modern society. While for a long time, it was possible to distinguish some function systems of society from others based on this form, today's professional work is more and more becoming an ordinary occupation, which nevertheless depends on outstanding competencies and promises above-average acquisition. Today, however, the ideal-typical form of this form of occupation is no longer professional work, but knowledge work that is not limited to single function systems - and includes the professions. With the end of the social form profession, on the one hand, no single occupational group can manage the knowledge of a function system anymore, and on the other hand, one can see from the fact that new knowledge is no longer only produced in the context of the science system that no single function system can be responsible for the relevant knowledge of society any longer. Whether knowledge occupations or knowledge work can take the place of the form profession or that of the science system may be doubted with good arguments.

However, is the end of the society-theoretical activity with the professions, described here, actually also the end of professions' research? Certainly not, because on the one hand, this discipline - at least in an international perspective - seems to be experiencing a new blossoming, without at the same time seeking a connection to classical sociology of the professions. On the other hand, one could ask to what extent the professions' characteristics developed by professions' research have spread to other areas of society. One might think, for example, of the form of solidarity among strangers cultivated by the classical professions, of the uncertainties in professional action, of the interaction between experts and clients, of the fact that the professional form of action and problem-solving today is similar to that found in modern knowledge occupations, and finally of the fact that professional sociological topics have been taken up in organizational research for several years. That includes, among other things, the special knowledge base - i.e., acting on a limited knowledge base and the forms of coping with 
uncertainty -, the orientation towards the common good, professional or business ethics, or the emphasis on client or customer relations. The end of society-theoretical engagement with the professions and the end of the social form profession described in this article does not seem to say anything about the significance of topics of professions' sociology (see Kurtz, 2006b).

Of course, one could now claim that occupations are becoming more and more aligned, in that the classical professions are losing some of their prominent importance and, at the same time, other occupations are taking over something from them and then becoming (new) professions themselves. In contrast, however, it is assumed here that the classical concept of profession today has only a historical significance. For a certain period in the history of society it had a special significance for the determination of early modern society and some function systems of modern society. Today, however, the classical professions have lost this significance and no further individual occupations can be imagined which could fill this significance for society or its function systems. For this reason, I have spoken here of an end of the social form profession.

But this end of the close network of relationships between profession and society described here does not at the same time also mean an end of the profession as a sociological category. In everyday language as well as in sociology, professions and their complementary terms such as ,professional', ,professionalism', ,professionalization", ,professional action", and ,professional performance" will continue to exist. But at least in sociology - for instance its theories but also its textbooks and teaching - the shift in meaning of the sociological category profession should be taken into account. We are therefore not yet dealing with an end of the profession as a sociological category, but rather with a readjustment of this category. On the one hand, there will no longer be any so-called leading professions that dominate the knowledge and action structures of individual sub-areas of society. And on the other hand, professions today and in the future will be more and more dependent on forms of cooperation with other professions so that multi-professional and multi-dimensional problem-solving are increasingly gaining in importance.

\section{Declarations}

Conflict of Interest The author states that there is no conflict of interest.

\section{References}

Abbott, A. (1988). The System of Professions. An Essay on the Division of Expert labor. The University of Chicago Press.

Abbott, A. (1995). Boundaries of SocialWork or SocialWork of Boundaries? Social Service Review, 69, 545562.

Aron, R. (1962). Dix-huit leçons sur la société industrielle. Gallimard.

Austin, M. J. L. (1978). Professionals and Paraprofessionals. Human Sciences Pr.

Beck, U. (1992). Risk Society. Towards a New Modernity. Sage.

Bell, D. (1973). The Coming of Post-Industriel Society. A Venture in Social Forecasting. Basic Books Inc.. Burawoy, M. (2005). 2004 Presidential Address: For Public Sociology. American Sociological Review, 70, 4 28.

Burrage, M. (1988). Unternehmer, Beamte und freie Berufe. Schlüsselgruppen der bürgerlichen Mittelschichten in England, Frankreich und den Vereinigten Staaten. In H. Siegrist (Ed.), Bürgerliche 
Berufe. Zur Sozialgeschichte der freien und akademischen Berufe im internationalen Vergleich (pp. 5183). Vandenhoeck \& Ruprecht.

Burrage, M., \& Torstendahl, R. (Eds.). (1990). Professions in Theory and History. Rethinking the Study of the Professions. SAGE Publications.

Cogan, M. L. (1953). Toward a Definition of Profession. Harvard Educational Review, 23, 33-50.

Durkheim, É. (1902). De la division du travail social. Alcan.

Etzioni, A. (Ed.). (1969). The Semi-Professions and Their Organization. Free Press.

Flexner, A. (1915). Is Social Work a Profession? School and Society, 1, 901-911.

Foucault, M. (1963). Naissance de la clinique: une archeologie du regard medical. Pr. Univ. de France.

Geison, G. L. (Ed.). (1983). Professions and Professional Ideologies in America. The University of North Carolina Press.

Geison, G. L. (Ed.). (1984). Professions and the French State, 1700-1900. University of Pennsylvania Press.

Gerhards, J. (2001). Der Aufstand des Publikums. Eine systemtheoretische Interpretation des Kulturwandels in Deutschland zwischen 1960 und 1989. Zeitschrift für Soziologie, 30, 163-184.

Giess, S. (1999). 'Merckwürdige Begebenheiten'. Wissensvermittlung im Volkskalender des 18. Jahrhunderts. Traverse. Zeitschrift für Geschichte, 6, 35-49.

Goode, W. J. (1960). Enchroachment, Charlatanism, and the Emerging Profession: Psychology, Sociology, and Medicine. American Sociological Review, 25, 902-914.

Gugerli, D. (1999). Soziotechnische Evidenzen. Der 'Pictorial Turn' als Chance für die Geschichtswissenschaft. Traverse. Zeitschrift für Geschichte, 6, 131-158.

Harries-Jenkins, G. (1970). Professionals in Organizations. In J. A. Jackson (Ed.), Professions and Professionalization (pp. 53-107). Cambridge University Press.

Hartmann, H. (1968). Arbeit, Beruf, Profession. Soziale Welt, 19, 193-216.

Huerkamp, C. (1980). Ärzte und Professionalisierung in Deutschland. Überlegungen zum Wandel des Arztberufs im 19. Jahrhundert. Geschichte und Gesellschaft. Zeitschrift für Historische Sozialwissenschaft, 6, 349-382.

Hughes, E. C. (1958a). Men and their Work. Free Press.

Hughes, E. C. (1958b). Professional and Career Problems of Sociology. In E. C. Hughes, Men and their Work (pp. 157-168). Free Press.

Hughes, E. C. (1963). Professions. Daedalus, 92, 655-668.

Kade, J., \& Lüders, C. (1996). Lokale Vermittlung. Pädagogische Professionalität unter den Bedingungen der Allgegenwart medialer Wissensvermittlung. In A. Combe \& W. Helsper (Eds.), Pädagogische Professionalität. Untersuchungen zum Typus pädagogischen Handelns (pp. 887-923). Suhrkamp.

Kurtz, T. (2000). Moderne Professionen und Gesellschaftliche Kommunikation. Soziale Systeme. Zeitschrift für soziologische Theorie, 6, 169-194.

Kurtz, T. (2004a). Zur Respezifikation der pädagogischen Einheitsformel. In D. Lenzen (Ed.), Irritationen des Erziehungssystems. Pädagogische Resonanzen auf Niklas Luhmann (pp. 12-36). Suhrkamp.

Kurtz, T. (2004b). Zur Multidimensionalität der Sozialen Arbeit. Neue Praxis, 34, 16-30.

Kurtz, T. (2005). Die Berufsform der Gesellschaft. Velbrück Wissenschaft.

Kurtz, T. (2006a). Unsicheres Handeln. Pädagogische Rundschau, 60, 549-558.

Kurtz, T. (2006b). Organisation, Profession und Gesellschaft. Sociologia Internationalis, 44, 275-294.

Kurtz, T. (2007). Sociological Theory and Sociological Practice. Acta Sociologica, 50, 283-294.

Kurtz, T. (2011). Der Professionsansatz von Niklas Luhmann. Soziale Systeme. Zeitschrift für soziologische Theorie, 17, 31-52.

Kurtz, T. (2013). Occupation as a Form and the Theory of Society. Cybernetics and Human Knowing, 20, $127-140$.

Kurtz, T. (2020). Sociological Observations of the Educational System: A Systems-Theoretical Perspective. European Educational Research Journal. September 28, 2020 (online first).

Larson, M. S. (1977). The Rise of Professionalism. A Sociological Analysis. University of California Press.

Lenzen, D. (1991). Krankheit als Erfindung. Medizinische Eingriffe in die Kultur. Fischer.

Luhmann, N. (n.d.). Professionelle Arbeit. MS Bielefeld.

Luhmann, N. (1977). Funktion der Religion. Suhrkamp.

Luhmann, N. (1987). Die Differenzierung von Politik und Wirtschaft und ihre gesellschaftlichen Grundlagen. In N. Luhmann, Soziologische Aufklärung 4. Beiträge zur funktionalen Differenzierung der Gesellschaft (pp. 32-48). Westdeutscher Verlag.

Luhmann, N. (2000). Art as a Social System. Stanford University Press.

Luhmann, N. (2002). Das Erziehungssystem der Gesellschaft. Suhrkamp.

Luhmann, N. (2008). Law as a Social System. Oxford University Press. 
Marshall, T. H. (1939). The Recent History of Professionalism in Relation to Social Structure and Social Policy. Canadian Journal of Economics and Political Science, 5, 325-340.

Marx, K., \& Engels, F. (1974/1848). Manifest der Kommunistischen Partei. In MEW, vol. 4 (pp. 459-493). Dietz.

McClelland, C. E. (1985). Zur Professionalisierung der akademischen Berufe in Deutschland. In W. Conze \& J. Kocka (Eds.), Bildungsbürgertum im 19. Jahrhundert, Teil I: Bildungssystem und Professionalisierung im internationalen Vergleich (pp. 233-247). Klett-Cotta.

Parsons, T. (1937). Remarks on Education and the Professions. International Journal of Ethics, 47, 365-369.

Parsons, T. (1939). The Professions and Social Structure. Social Forces, 17, 457-467.

Parsons, T. (1954). A Revised Analytical Approach to the Theory of Social Stratification. In T. Parsons, Essays in Sociological Theory (revised ed., pp. 386-439). Free Press.

Parsons, T. (1959). Some Problems Confronting Sociology as a Profession. American Sociological Review, $24,547-559$.

Parsons, T. (1968a). Professions. International Encyclopedia of the Social Science, 12, 536-547.

Parsons, T. (1968b). The Structure of Social Action. A Study in Social Theory with Special Reference to a Group of Recent European Writers. Free Press.

Parsons, T. (1971). The System of Modern Societies. Prentice-Hall.

Parsons, T. (1978). Research with Human Subjects and the 'Professional Complex'. In T. Parsons, Action Theory and the Human Condition (pp. 35-65). Free Press.

Parsons, T., \& Platt, G. M. (1973). The American University. Harvard Univ. Press.

Schimank, U. (2001). Organisationsgesellschaft. In G. Kneer, A. Nassehi, \& M. Schroer (Eds.), Klassische Gesellschaftsbegriffe der Soziologie (pp. 278-307). Fink.

Schütz, A. (1946). The Well-Informed Citizen: An Essay on the Social Distribution of Knowledge. Social Research, 13, 463-478.

Schulze, G. (1992). Die Erlebnisgesellschaft. Kultursoziologie der Gegenwart. Campus.

Siegrist, H. (1988). Bürgerliche Berufe. Die Professionen und das Bürgertum. In H. Siegrist (Ed.), Bürgerliche Berufe. Zur Sozialgeschichte der freien und akademischen Berufe im internationalen Vergleich (pp. 1148). Vandenhoeck \& Ruprecht.

Spencer, H. (1966). The Principles of Sociology, Vol. III. Reprint of the Edition of 1897. Otto Zeller.

Stehr, N. (1994). Knowledge Societies. Sage.

Stichweh, R. (1980). Rationalität bei Parsons. Zeitschrift für Soziologie, 9, 54-78.

Stichweh, R. (1992). Professionalisierung, Ausdifferenzierung von Funktionssystemen, Inklusion. Betrachtungen aus systemtheoretischer Sicht. In B. Dewe, W. Ferchhoff, \& F.-O. Radtke (Eds.), Erziehen als Profession. Zur Logik professionellen Handelns in pädagogischen Feldern (pp. 36-48). Leske + Budrich.

Stichweh, R. (1996). Professionen in einer funktional differenzierten Gesellschaft. In A. Combe \& W. Helsper (Eds.), Pädagogische Professionalität. Untersuchungen zum Typus pädagogischen Handelns (pp. 4969). Suhrkamp.

Stichweh, R. (1997). Professions in Modern Society. International Review of Sociology, 7, 95-102.

Stichweh, R. (2005). Wissen und die Professionen in einer Organisationasgesellschaft. In T. Klatetzki \& V. Tacke (Eds.), Organisation und Profession (pp. 31-44). VS Verlag.

Stichweh, R. (2006). Strukturbildung in der Weltgesellschaft. Die Eigenstrukturen der Weltgesellschaft und die Regionalkulturen der Welt. In T. Schwinn (Ed.), Die Vielfalt und Einheit der Moderne (pp. 241-259). VS Verlag.

Stolberg, M. (2004). Frühneuzeitliche Heilkunst und ärztliche Autorität. In R. van Dülmen \& S. Rauschenbach (Eds.), Macht des Wissens. Die Entstehung der modernen Wissensgesellschaft (pp. 111130). Böhlau Verlag.

Toren, N. (1977). Social Work: The Case of a Semi-Profession. Sage Publ.

Waddington, I. (1978). Power and Control in the Doctor-Patient Relationship: A Developmental Analysis. University of Leicester.

Weber, M. (1985). The protestant ethic and the spirit of capitalism. Unwin.

Wilensky, H. (1964). The Professionalization of Everyone? American Journal of Sociology, 70, 137-158. 